\title{
Producing Natural Vitamin A by Enzymatic Oxidation of Natural $\beta$-Carotene
}

\author{
Sadeq Emeish \\ Al-Balqa' Applied University, Faculty of Engineering Technology \\ Department of Chemical Engineering P.O.Box (15008), 11134 Marka, Amman-Jordan
}

\begin{abstract}
This study investigates the feasibility of $\beta$-carotene production from Dunaliella salina isolated from the Dead Sea employing a number of interdependent steps and focusing on the laboratory scale cultures. Then the produced $\beta$-Carotene was subjected to enzymatic oxidation using the enzyme 15,15 ' $\beta-\beta$ carotene dioxygenase to produce tretinoin (vitamin A). The produced vitamin A was verified using proper analysis.

Dunaliella salina was isolated from the Dead Sea and cultivated using a certain media until the cell count was 6 million cell/ml, then it was centrifuged and extracted using organic solvents and oils like jojoba oil and ethanol. The extracted $\beta$-carotene was subjected to enzymatic oxidation in a bioreactor under inert atmosphere of nitrogen. Freeze drying step was performed to obtain vitamin A as powder. The produced vitamin A powder was of a very high purity, and it has a very strong economic potentiality.
\end{abstract}

Keywords: - $\beta$-Carotene, Cultivation, Dunaliella salina, Freeze Drying, Vitamin A.

\section{INTRODUCTION}

The Dead Sea is called the salts sea, is a salt lake with $67 \mathrm{~km}$ long and (18) $\mathrm{km}$ width at the widest point. The Dead Sea has a density of (1.24) kg/l which makes swimming similar to floating. The Dead Sea was composed of two stratified layers of water that differed in temperatures, density, age and salinity. The mineral contact of the Dead Sea is very different from other ocean water, the exact composition of the Dead Sea water varies mainly with season, depth and temperature. Researches from Hebrew university found the Dead Sea to be teeming with type of alge called dunaliella [1].The dunaliella in turn nourished carotenoid containing (red pigmented) halobacter whose presence caused the color change [2].

In recent decades, the Dead Sea has been rapidly shrinking because of diversion of incoming water from the Jordan River to the north. The southern end is fed by a canal maintained by the Dead Sea Works, a company that converts the sea's raw materials. From a depression of $395 \mathrm{~m}(1,296 \mathrm{ft})$ below sea level in 1970 it fell $22 \mathrm{~m}$

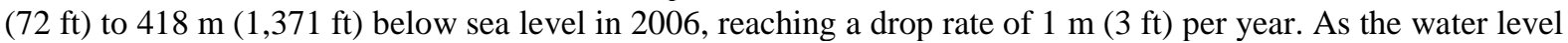
decreases, the characteristics of the Sea and surrounding region may substantially change. The water level is

now $-425 \mathrm{~m}$.

The Dead Sea level drop has been followed by a groundwater level drop, causing brines that used to occupy underground layers near the shoreline to be flushed out by freshwater. This is believed to be the cause of the recent appearance of large sinkholes along the western shore incoming freshwater dissolves salt layers, rapidly creating subsurface cavities that subsequently collapse to form these sinkholes.

The dead sea climate offer year round sunny skies and dry air ,it has less than (50)mm mean annual rainfall and summer average temperature between $\left(32 c^{\circ}\right)$ and $\left(39 c^{\circ}\right)$, winter average temperature range between $\left(20 c^{\circ}\right)$ and $\left(23 \mathrm{c}^{\circ}\right.$ ) (Abusara et al, 2011). The region has weakened ultra violate radiation, particularly the UVB (erythrogenic rays), and an atmosphere characterized content due to the higher barometric pressure by to increase oxygen. The climate data of the Dead Sea is shown in Figure (1). 
Producing Natural Vitamin A by Enzymatic Oxidation of Natural $\beta$-Carotene

\begin{tabular}{|c|c|c|c|c|c|c|c|c|c|c|c|c|c|}
\hline Month & Jan & $\mathrm{Feb}$ & Mar & Apr & May & Jun & Jul & Aug & Sep & Oct & Nov & Dec & Year \\
\hline Record high ${ }^{\circ} \mathrm{C}$ & 26.4 & 30.4 & 33.8 & 42.5 & 45.0 & 46.4 & 47.0 & 44.5 & 43.6 & 40.0 & 35.0 & 28.5 & 47.0 \\
\hline Average high ${ }^{\circ} \mathrm{C}$ & 20.5 & 21.7 & 24.8 & 29.9 & 34.1 & 37.6 & 39.7 & $39.0)$ & 36.5 & 32.4 & 26.9 & 21.7 & 30.4 \\
\hline Average low ${ }^{\circ} \mathrm{C}$ & 12.7 & 13.7 & 16.7 & 20.9 & 24.7 & 27.6 & 29.6 & 29.9 & 28.3 & 24.7 & 19.3 & 14.1 & 21.9 \\
\hline Record low ${ }^{\circ} \mathrm{C}$ & 5.4 & 6.0 & 8.0 & 11.5 & 19.0 & 23.0 & 26.0 & 26.8) & 24.2 & 17.0 & 9.8 & 6.0 & 5.4) \\
\hline Precipitation mm) & 7.8 & 9.0 & 7.6 & 4.3 & 0.2 & 0.0 & 0.0 & 0.0 & 0.0 & 1.2 & 3.5 & 8.3) & 41.9 \\
\hline$\%$ humidity & 41 & 38 & 33 & 27 & 24 & 23 & 24 & 27 & 31 & 33 & 36 & 41 & 31.5 \\
\hline $\begin{array}{l}\text { Avg. precipitation } \\
\text { days }\end{array}$ & 3.3 & 3.5 & 2.5 & 1.3 & 0.2 & 0.0 & 0.0 & 0.0 & 0.0 & 0.4 & 1.6 & 2.8 & 15.6 \\
\hline
\end{tabular}

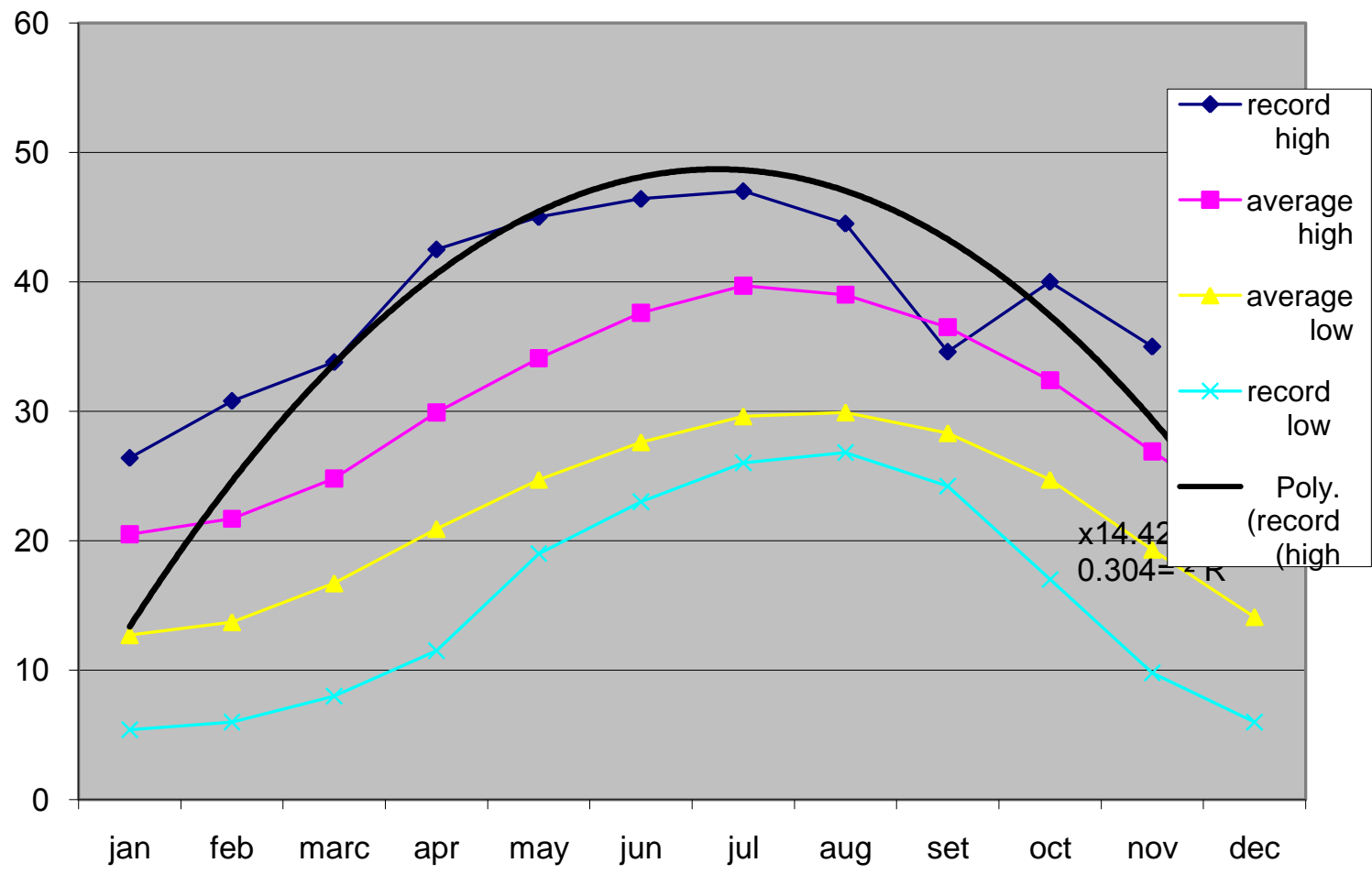

Figure (1):Temperature distribution throughout the year for the Dead Sea climate

\subsection{Dunaliella salina}

Dunaliella salina is a type of halophile green micro-algae especially found in sea salt fields. Known for its anti-oxidant activity because of its ability to create large amount of carotenoids, it is used in cosmetics and dietary supplements. Few organisms can survive in such highly saline conditions as salt evaporation ponds. To survive, these organisms have high concentrations of $\beta$-carotene to protect them against the intense light, and high concentrations of glycerol to provide protection against osmotic pressure. This offers an opportunity for commercial biological production of these substances [3].

From a first pilot plant for Dunaliella cultivation for $\beta$-carotene production established in the USSR in 1966, the commercial cultivation of Dunaliella for the production of $\beta$-carotene throughout the world is now one of the success stories of homophile biotechnology. Different technologies are used, from low-tech extensive cultivation in lagoons to intensive cultivation at high cell densities under carefully controlled conditions. Although Dunaliella Salina produce $\beta$-Carotene in a high salt environment, archaea such as Halo bacterium, not Dunaliella, are responsible for the red and pink coloring of salt lakes [4].Occasionally, orange patches of Dunaliella colonies will crop up Attempts have been made to exploit the high concentrations of glycerol accumulated by Dunaliella as the basis for the commercial production of this compound. Although technically the production of glycerol from Dunaliella was shown to be possible, economic feasibility is low and no biotechnological operation presently (July 2005) exists that exploits the alga for glycerol production [5]. 


\subsection{Beta-Carotene and Vitamin A}

\section{THEORY}

Beta-Carotene is an organic compound and classified as terpenoid. It is a fat-soluble compounds naturally present in many fruits, grains, oils and vegetables (green plants, carrots, spinach, and

green peppers), and sometimes added to foods or vitamin supplements as a nutrient $\beta$-carotene is stronglycoloured pigment $\beta$-carotene is composed of two retinyl groups . $\beta$-carotene has anti-oxidant properties and it can absorb in the visible region strongly between $400-500 \mathrm{~nm}$, this is because of the $\beta$-carotene properties as shown in Error! Reference source not found.. $\beta$-carotene is known as provitamin A [6].

Table Error! No text of specified style in document.-1: Properties of $\boldsymbol{\beta}$-carotene.

\begin{tabular}{|l|l|} 
Molecular Formula & $\mathrm{C}_{40} \mathrm{H}_{56}$ \\
\hline Molar mass & $536.87 \mathrm{~g} / \mathrm{mol}$ \\
\hline Exact mass & $536.438201792 \mathrm{~g} / \mathrm{mol}$ \\
\hline Appearance & Dark orange crystals \\
\hline Density & $0.94 \mathrm{~g} / \mathrm{cm}$ \\
\hline Melting point & $180-182^{\circ} \mathrm{C}\left(356-360^{\circ} \mathrm{F}\right)$ \\
\hline Boiling point & $663-677^{\circ} \mathrm{C}\left(1171-1251^{\circ} \mathrm{F}\right)$ \\
\hline
\end{tabular}

Vitamin A is a fat soluble vitamin that is stored in liver. It contributes to normal growth and development while keeping eyes, skin and immune system healthy. Vitamin A usually comes from animal food source, but it can also made from compounds found in plant found in plant foods, called carotenoids like beta-carotene are found in plants such as dark or yellow vegetables and carrots [7].

- Vitamin A can be in the form of:

- Retinyl Esters: this is the Vitamin A form found in animal products.

- Beta-carotene: this is the Vitamin A form found in plant source.

- Retinol: this is the major form of Vitamin A which gets to travel throughout the body. It is also supports the skin's immune function.

- Retinal: this is the form needed to help with night vision.

- Retinoic acid: this is the form act as a hormone, at which it affect the genes of the cell and helps in the proteins synthesis.

- Retinyl Palmitate: this is the storage form found in liver .

Retinol, retinalaldehyde and retinoic acid are collectively known as Vitamin A.Vitamin A is necessary needed for maintenance of the healthy epithelial tissue and can prevent the inception or progress of skin cancers by stimulating normal cell differentiation .. B-carotene is an excellent source of Vitamin A; because the $\beta$-carotene is converted into Vitamin $\mathrm{A}$ in the body There are two ways in which $\beta$-carotene can be converted to Vitamin $\mathrm{A}$. a. $\quad$ By breaking the $\beta$-carotene molecule from one end.

b. By cleavage at the center.

In the molecule chain between the two cyclohexyl rings $\beta$-carotene cleaves either by symmetrically or asymmetrically; at which symmetric cleavage is done by using an enzyme called beta-carotene-15,15'dioxygenase in the human body, this gives two equivalent retinal molecules and each retinal molecule reacts to give retinol (Vitamin A) and retinoic acid as shown Figure (2.1).<smiles>CC(C=CC=C(C)C=CC(C)=CC=CC(C)=CC=CC(C)=CC=CC1=C(C)CCCC1(C)C)=CC=CC=C(C)C=CC=C(C)C=CC1C(C)=CCCC1(C)C</smiles>

Figure( Error! No text of specified style in document..1): $\beta$-carotene and Vitamin A structure. 
Vitamin A can be synthesized by reduction reaction, at which the retinal reduced to retinol by retin ldehyde reduced in the intestines; this is reduction of an aldehyde by the addition of hydrogen atoms to make retinol as Figure( 2.2).

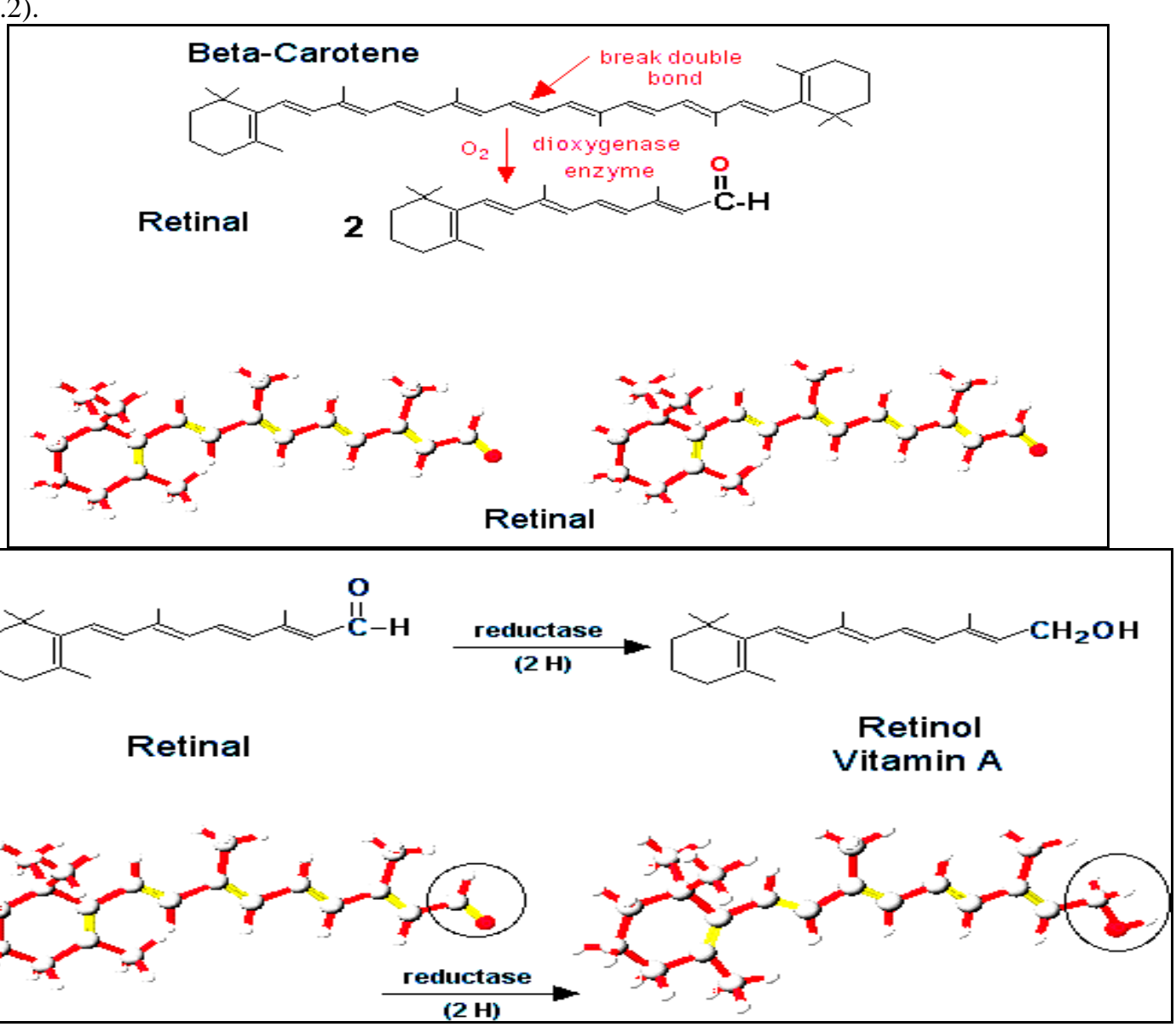

Figure( Error! No text of specified style in document..2): synthesis of Vitamin A from $\beta$-carotene.

The retinoid are the active forms of Vitamin A and so there are a number of chemical reactions that occurs in the body to convert the carotenoids into retinoids, the interconversion of the preformed and provitamin $\mathrm{A}$ in the liver and intestinal cells is shown in Figure (2.3).

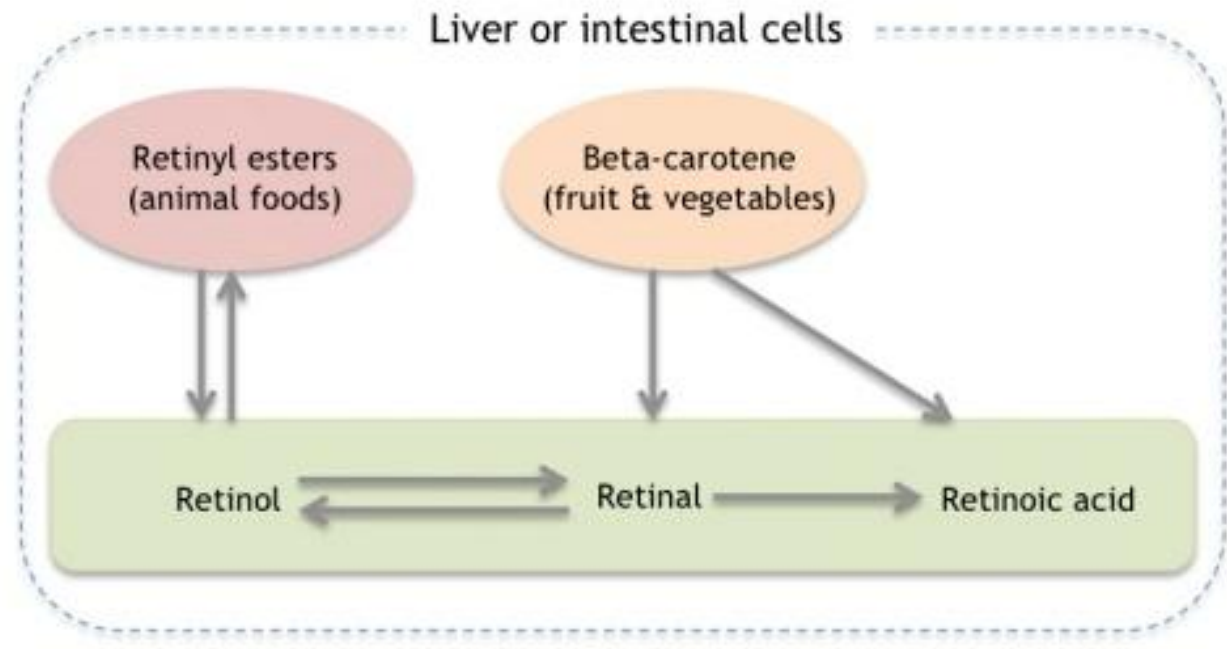

Figure( Error! No text of specified style in document.3): Inter conversion of preformed and pro vitamin A in the liver and intestinal cells.

Figure( 2.4) shows how the different forms of Vitamin A relate to each other . Vitamin A can get from either plant food source or from animal food source. Both have different ways of being converted into the many 
different forms of Vitamin A. The Vitamin A from the animal source is called as 'preformed Vitamin A' in the form of Retinyl Esters; because of its structure, it can easily converted to Retinol. Retinol is the most common form of Vitamin A in the body and it is used to transport Vitamin A throughout the body.

On the other side, Vitamin A from the plant source is called as 'provitamin A', the mostly form is beta-carotene. The body has two options to deal with the beta-carotene:

1- $\quad$ Use the beta-carotene as an antioxidant.

2- $\quad$ Use beta-carotene to be converted into Retinal.

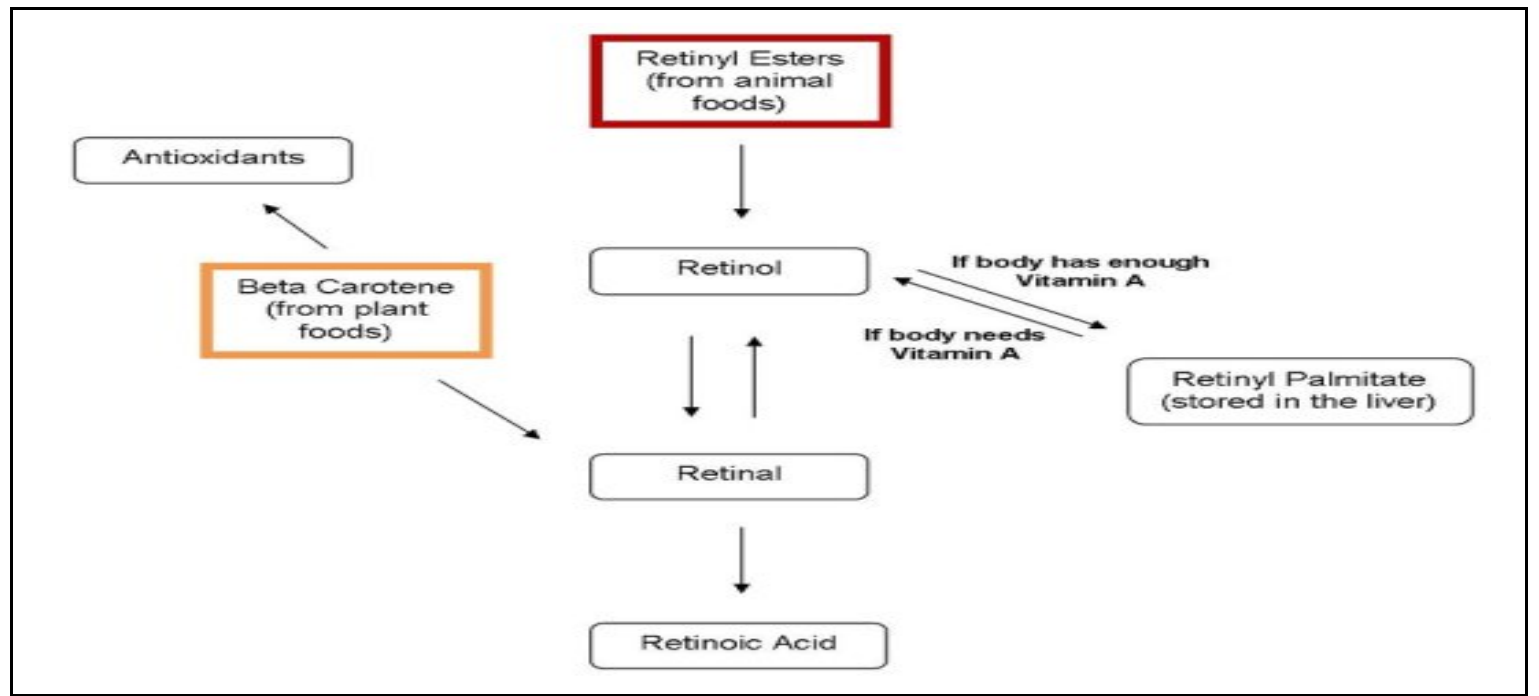

Figure( Error! No text of specified style in document..4): The relationship between different forms of Vitamin A.

METHODOLOGY

3.1 General approach for the extraction of beta-carotene from Dunaliella cells :

The sample from the saline Dead Sea water

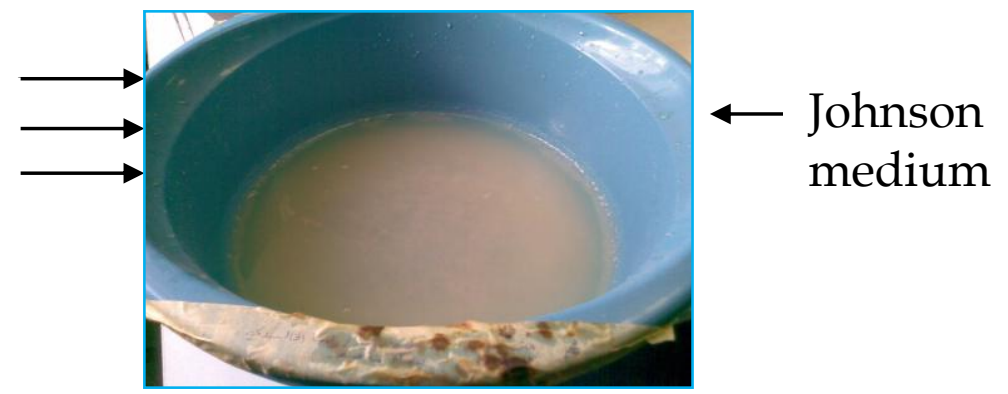

Figure (3.1) Cultivation pond
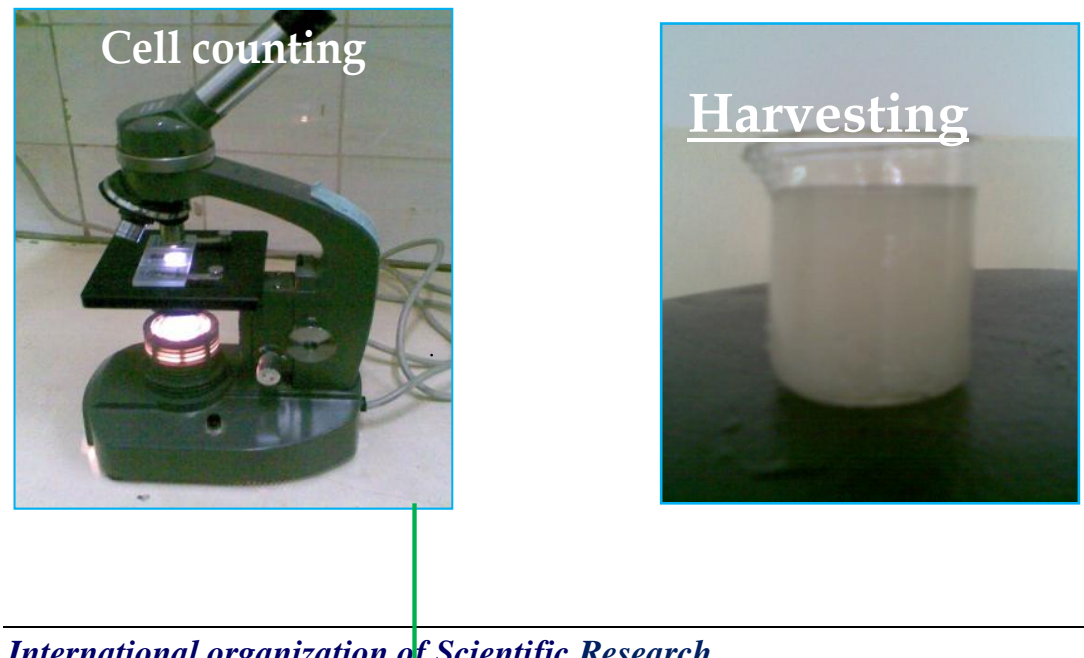


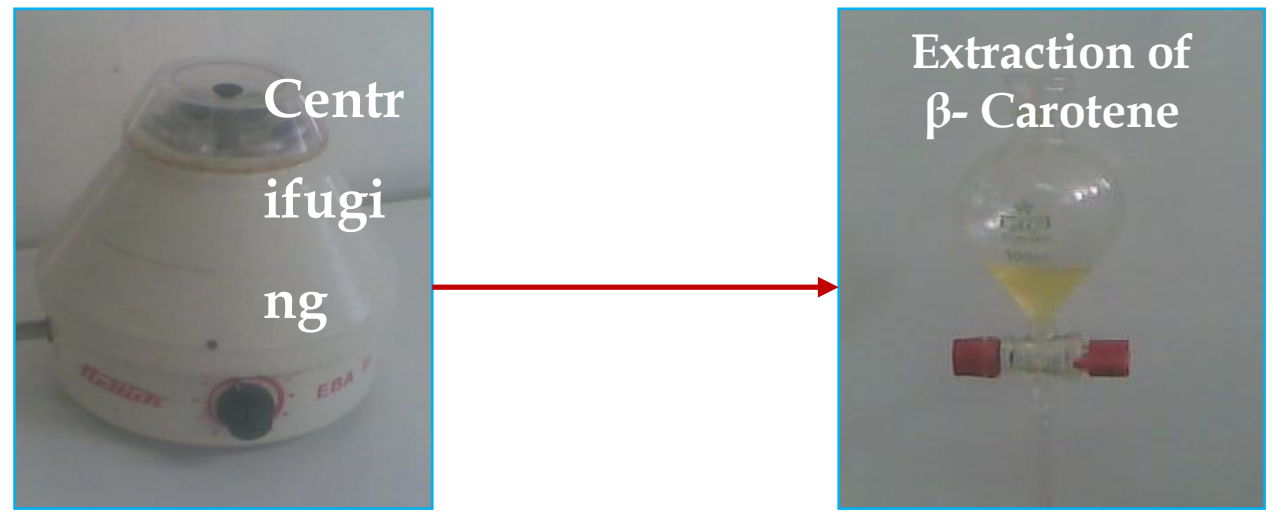

Figure (3.2) : $\beta$-carotene extraction pathway

Figure (3.1) shows the cultivation pond, and Figure (3.2) shows the $\beta$-carotene extraction pathway.

3.2 The production of vitamin A(tretinoin) from $\beta$-carotene by enzymatic oxidation :

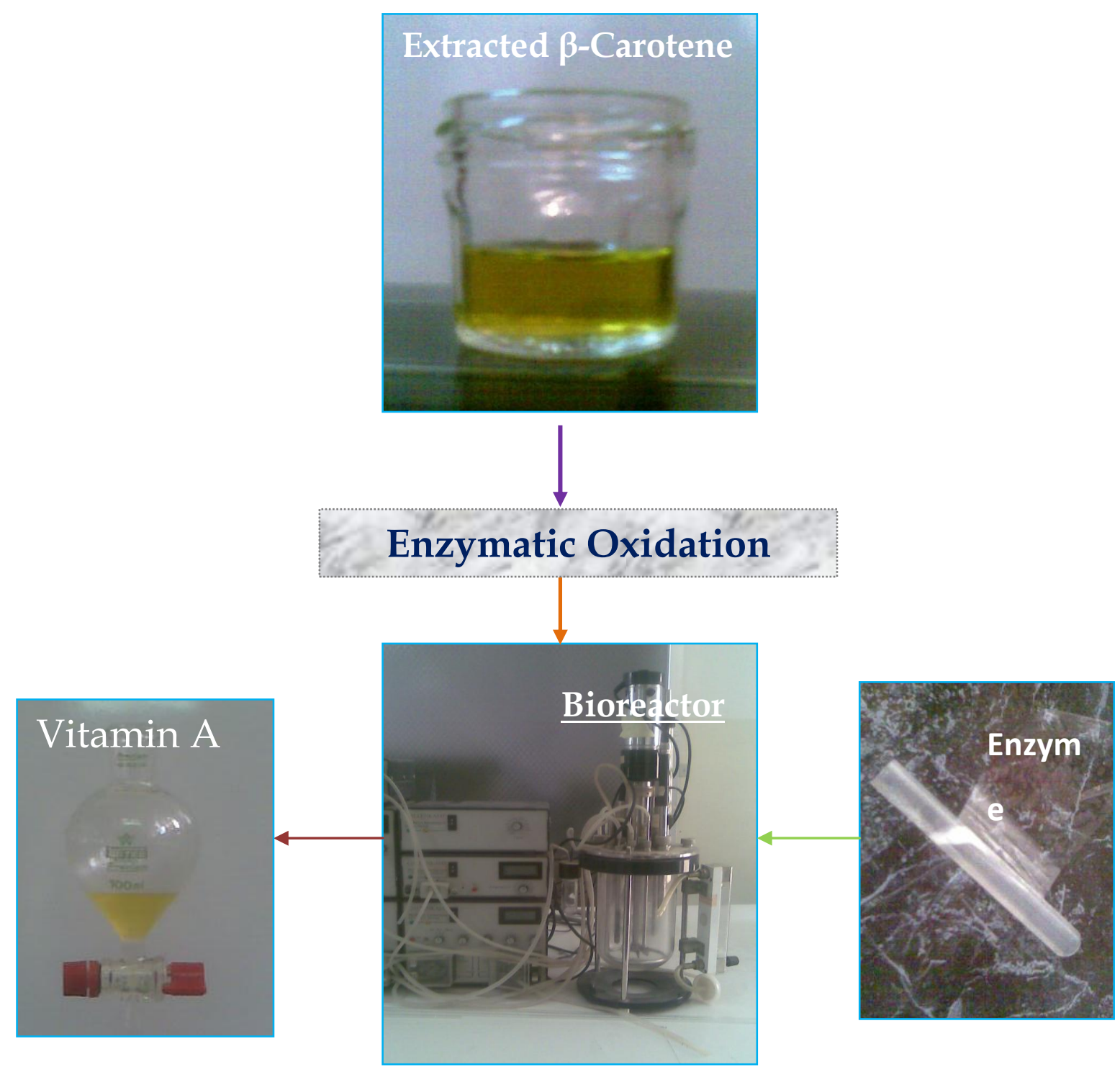


Figure (3.2) :Production of vitamin A pathway

\subsubsection{Cultivation:}

Two modes of cultivation are being used in large scale bioreactors of Dunaliella. In the more common the intensive mode is made to control all factors affecting cell growth and chemistry. In the other mode the extensive growth, Dunaliella grow very slowly in nearly saturated brine where the high salt concentration is used to control consistent production of $\beta$-carotene [8].

Dunaliella is cultivated in suitable environment like shallow tanks,

bioreactors, man-made or natural ponds at a range of temperature of $25-45^{\circ} \mathrm{C}$ and a very wide $\mathrm{pH}$ tolerance ranging from $\mathrm{pH} 1$ to $\mathrm{pH} 11$. It can cope with a salinity range from seawater $(3-31 \% \mathrm{NaCl})$.

The best media of cultivation can be prepared either by the addition of saline sea water or using Johnson Medium [9].

\subsubsection{Cell Counting:}

Hemocytometer was used for direct cell counting. In this method, a calibrated grid is placed over the culture chamber and the number of cells per grid square is counted using a microscope. At least 20 grid squares must be counted and averaged.

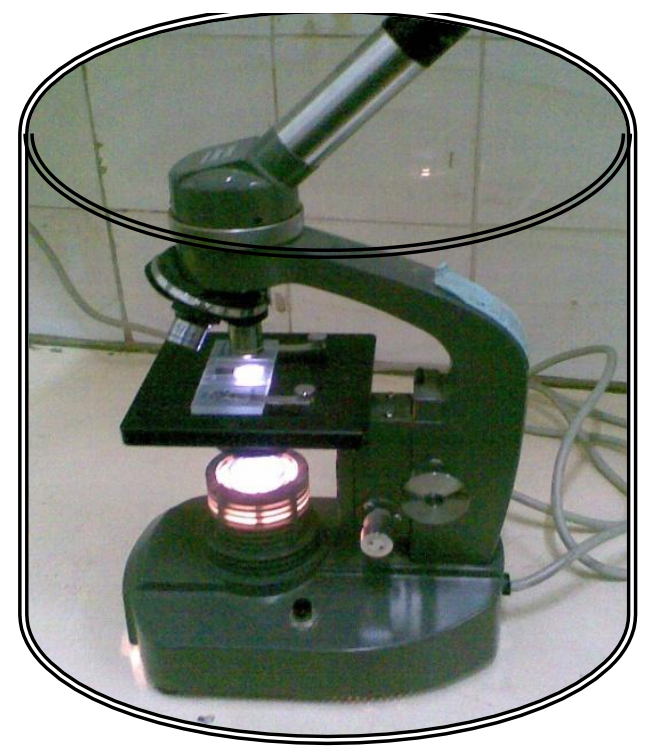

\subsubsection{Harvesting}

Figure( 3.1. 2):Hemocytometer

After the cultivated sample reaches the desired cell number ( about 780 million cell $/ \mu$ ), dunaliella can be harvested from the bond.

Dunaliella is a single cell with no protective cell wall, approximately $20 \times 10$ um in size and buoyant in a high specific gravity and high viscosity brine, so the harvesting will be difficult. The slurry may be passed through screens to allow the algae pass through and remove larger unwanted species.

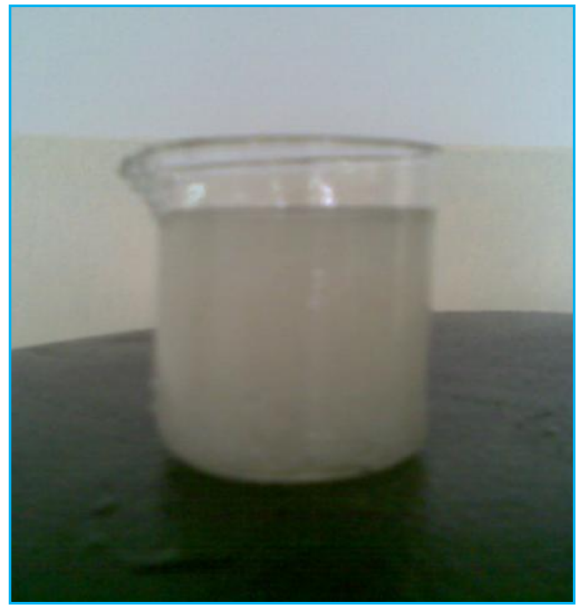




\section{Figure(3.1.3): Harvested sample}

\subsubsection{Centrifugation:}

Centrifugations generally tend to shear-damage the cells, leading to loss of $\beta$ - carotene by oxidation. The harvested sample.was centrifuged at $4000 \mathrm{rpm}$ for 15 minutes to obtain thick precipitate and clean upper layer which is continuously removed. The supernatant madia (upper clean layer) was recovered with a pipette to holding ponds to be transferred back to the growth ponds.

\subsubsection{Extraction}

Before the beginning with the extraction step it was preferred to wash the sample with hot distilled water to get rid of precipitated salts. Extraction of $\beta$-carotene from Dunaliella was carried out by solvents such as Jojoba oil, petroleum ethers, pentane, ethyl acetate, acetone, ethyl alcohol or n-hexane using a separatory funnel. The change of the extract layer gave a good indication for the presence of the extracted $\beta$ carotene [10]. When performing the solvent extraction to leach out $\beta$-carotene, two layers resulted; the upper one which was the extract and consists of the solvent with $\beta$-carotene while the other layer has the tissues of the alga suspended in the aqueous phase.

3.2.1 Enzymatic oxidation

The bioreactor must be calibrated before using it to carry out the enzymatic oxidation reaction to choose the best speed which gives the homogeneity of the reaction mixture. The best conditions were found to be at $250 \mathrm{rpm}$. Tretinoin can be obtained by the enzymatic oxidation of $\beta$-carotene using 15,15 '- $\beta, \beta$-Carotene dioxygenase enzyme in a stirred tank fermenter. In the reactor the temperature must be adjusted at $35^{\circ} \mathrm{C}$ and $\mathrm{pH}$ range $(4$ -5 ) by using puffer solution. The reaction time was one hour.

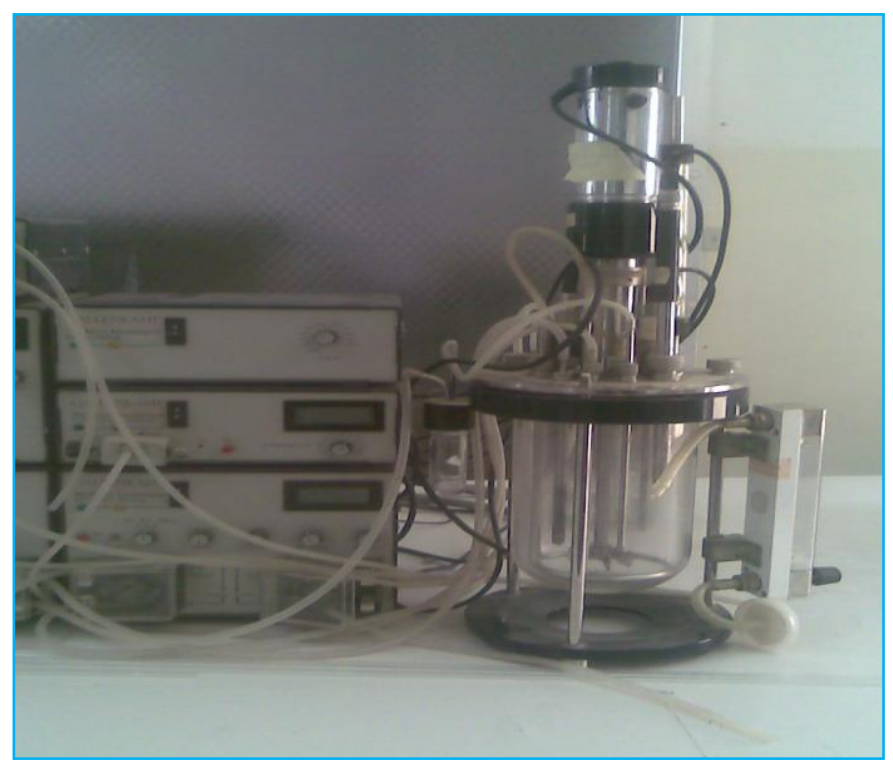

Figure(3.2.1) : Bioreactor used in the process

\subsection{IR spectroscopy:}

A beam of infrared light is produced and split into two separate beams. One is passed through the sample, the other passed

through a reference which is often the substance the sample is dissolved in. The beams are both reflected back towards a detector, however first they pass through a splitter which quickly alternates which of the two beams enters the detector. The two signals are then compared and a printout is obtained.

\subsection{Cell counting:}

\section{RESULTS}

The cultivation of cells was detected by cell counting using Hemocytometer weekly for 3 months to notice the cells growth behavior .

Cell number started with $700 \mathrm{cell} / \mu \mathrm{l}$ and finally reached 780 million cell $/ \mu 1$. 


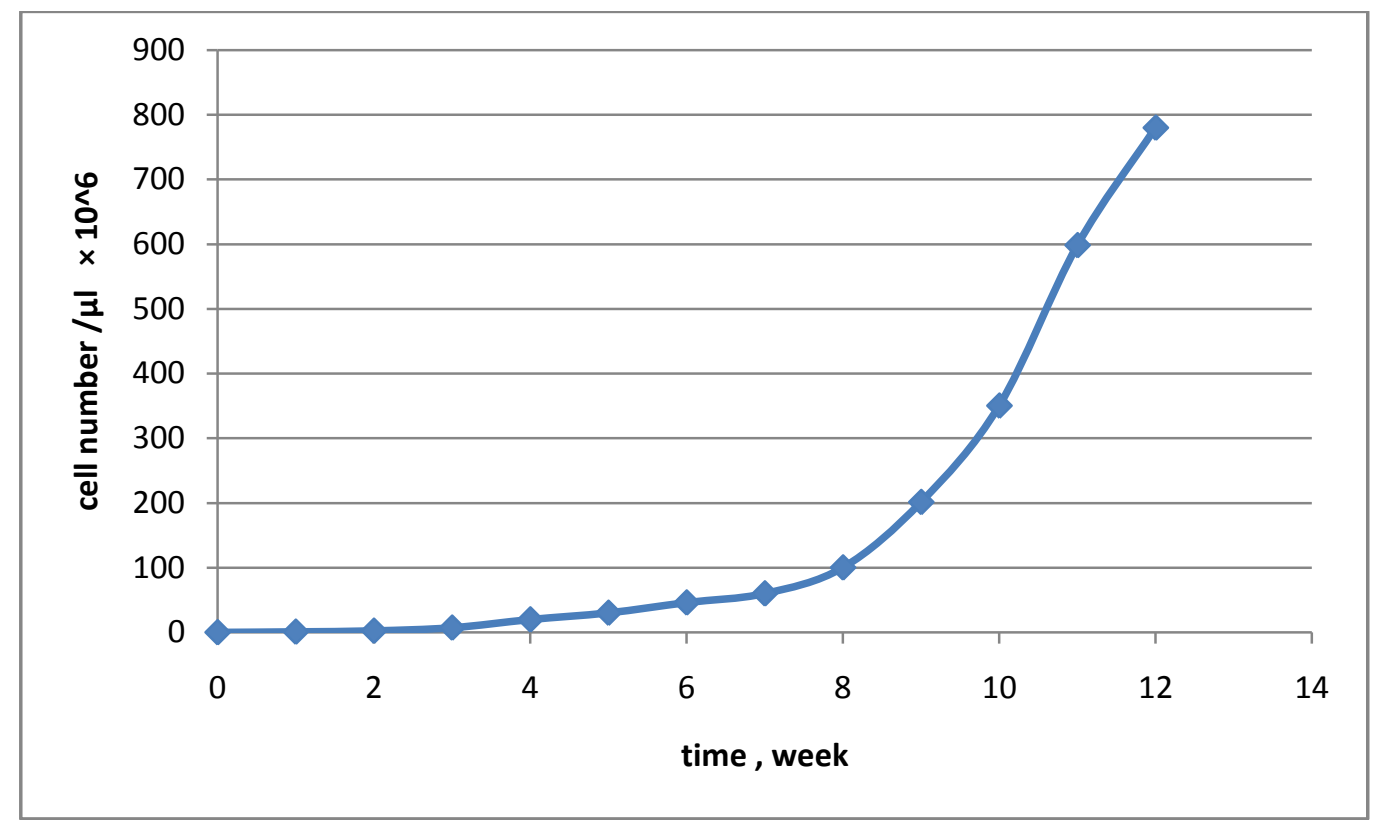

Figure(4.1) : Cell growth rate

\subsection{Centrifugation :}

- Centrifugation at $4000 \mathrm{rpm}$ for $15 \mathrm{~min}$.

- The average thick precipitate obtained to be subjected for extraction was ( $2.885 \mathrm{gr}$ ) as can be seen from table (4.1).

Table (4.1): Centrifugation results

\begin{tabular}{|ll|}
\hline Trial \# & Amount of thick precipitate (gr) \\
\hline Trial (1) & 2.89 \\
\hline Trial (2) & 2.885 \\
\hline Trial (3) & 2.88 \\
\hline \hline Average & 2.885 \\
\hline
\end{tabular}

\subsection{Extraction :}

- Adding $50 \mathrm{ml}$ of jojoba oil to the precipitate cells of $2.885 \mathrm{gr}$, resulted in a color change from light to dark yellow as shown in Figure (4.3).

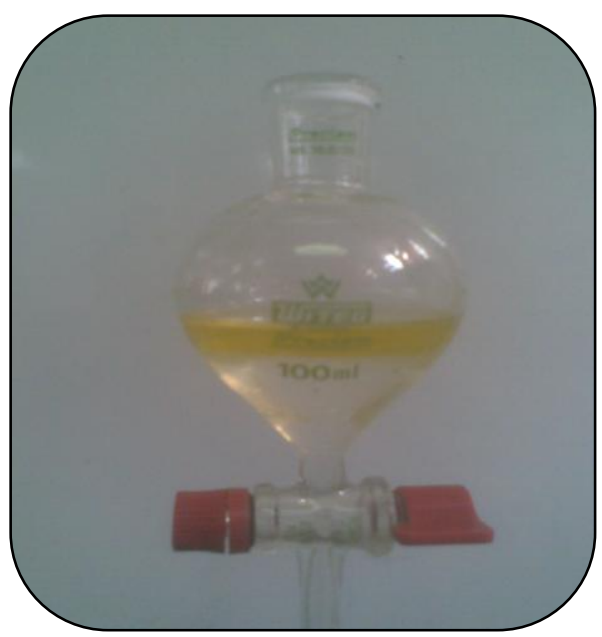

Figure (4.3) Extracted $\beta$ - carotene 


\subsection{Qualitative analysis :}

The qualitative analysis of the products accomplished by using several techniques and instruments such as IR spectrophotometer which was used to indicate the presence of $\beta$ -

carotene in extract solution and the vitamin A obtained after the oxidation in the reactor.

\subsubsection{IR results for $\beta$-Carotene :}

The sharpest peak of IR chromatogram for $\beta$-carotene solution appeared at a wave number $=2905.5 \mathrm{~cm}^{-1}$ Figure (4.4.1.1) IR chromatogram of $\beta$-carotene, sample 1.

The sharpest peak of IR chromatogram for $\beta$-Carotene solution appears at a wave number $=2868.8 \mathrm{~cm}^{-1}$, sample 2

Figure (4.4.1.2) :IR chromatogram of $\beta$-carotene, sample 2

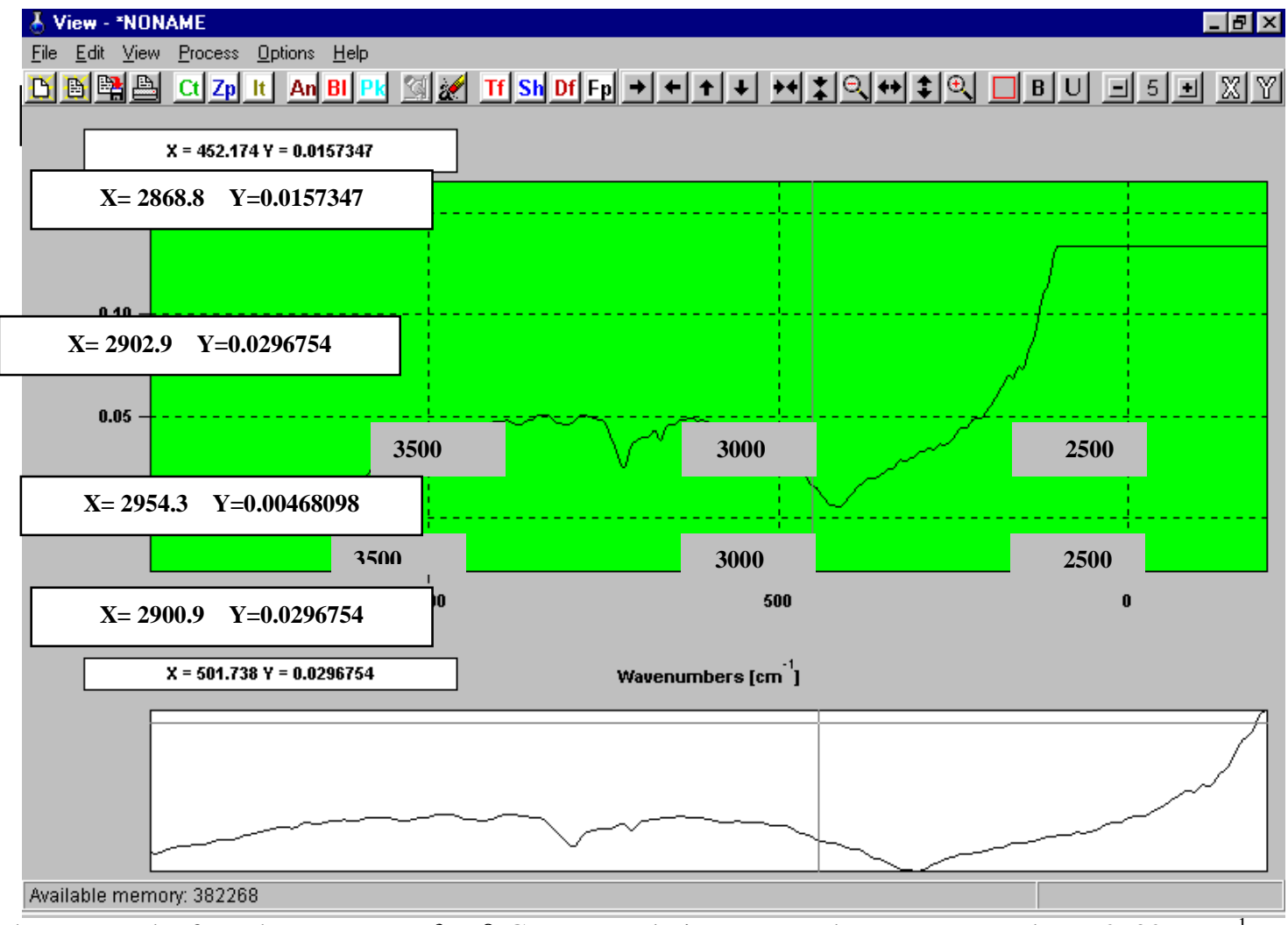

The sharpest peak of IR chromatogram for $\beta$-Carotene solution appeared at a wave number $=2902.9 \mathrm{~cm}^{-1}$

Figure (4.4.1.3): IR chromatogram of $\beta$-carotene, sample 3

\subsubsection{IR results for standard vitamin $A$ :}




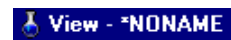

File É dit View Process $\underline{\text { Qptions }}$ Help

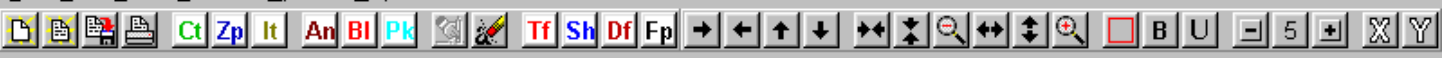
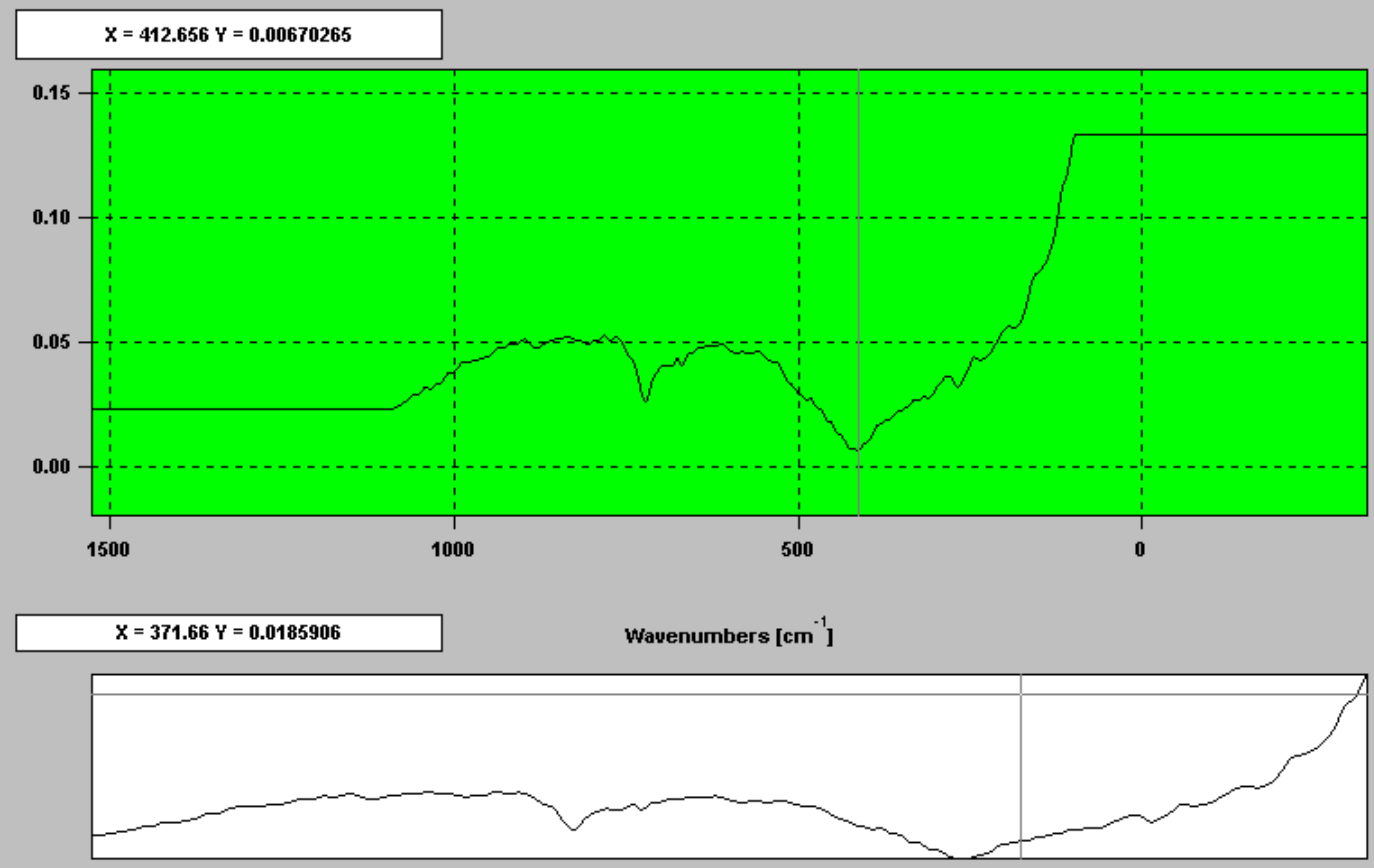

Available memory: 415300

\section{View - XNONAME}

File Edit View Process $\underline{\text { Qptions }}$ Help

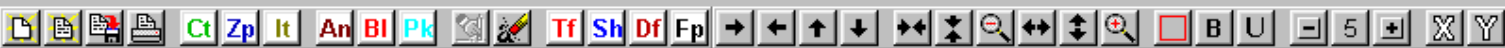
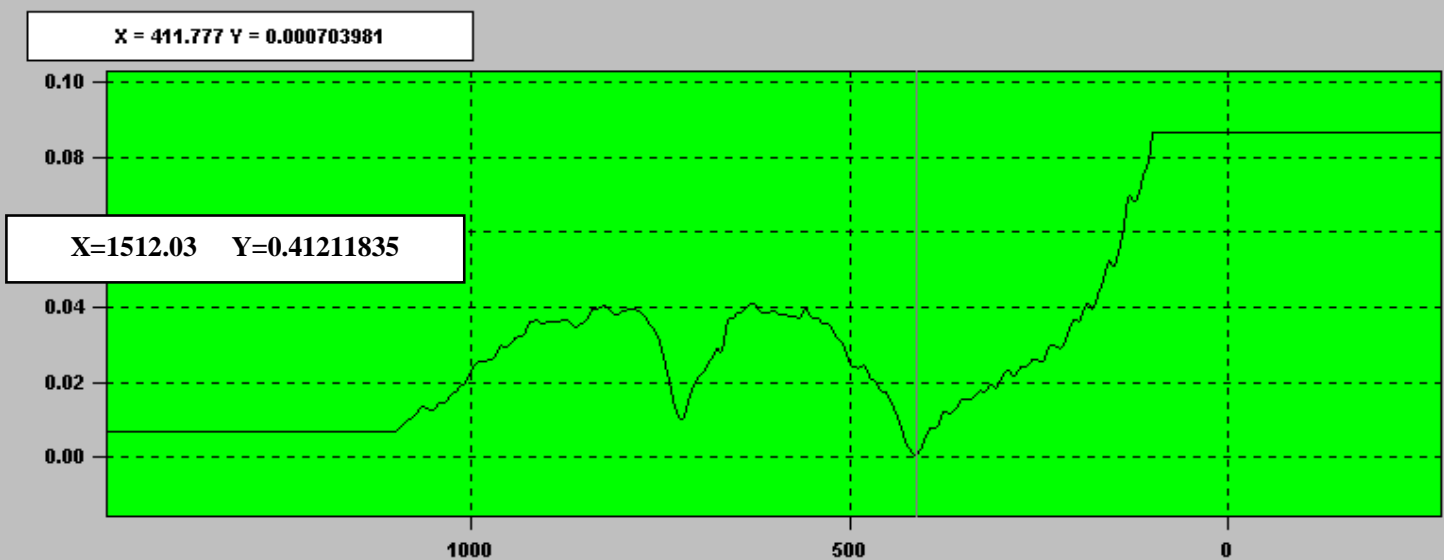

$X=401.352 Y=0.00468098$

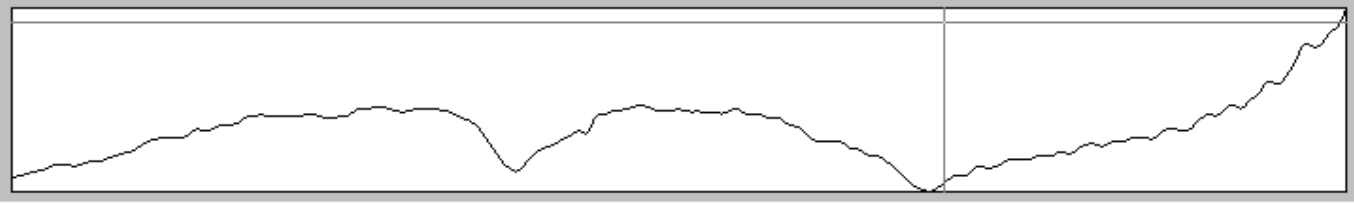

Available memory: 367180

The sharpest peak of IR chromatogram for standard Vitamin A have a wave number range ( 1512.03 -2920.02) $\mathrm{cm}^{-1}$. 
Figure (4.4.2.1) :IR chromatogram of standard Vitamin A

\subsubsection{IR results for vitamin A:}

\section{$B$ View - xyitamin A [100-1000).SPE}

File Edit View Process Options Help

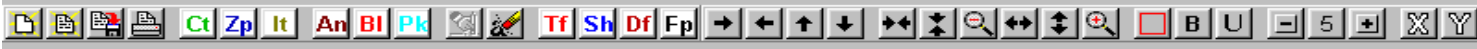
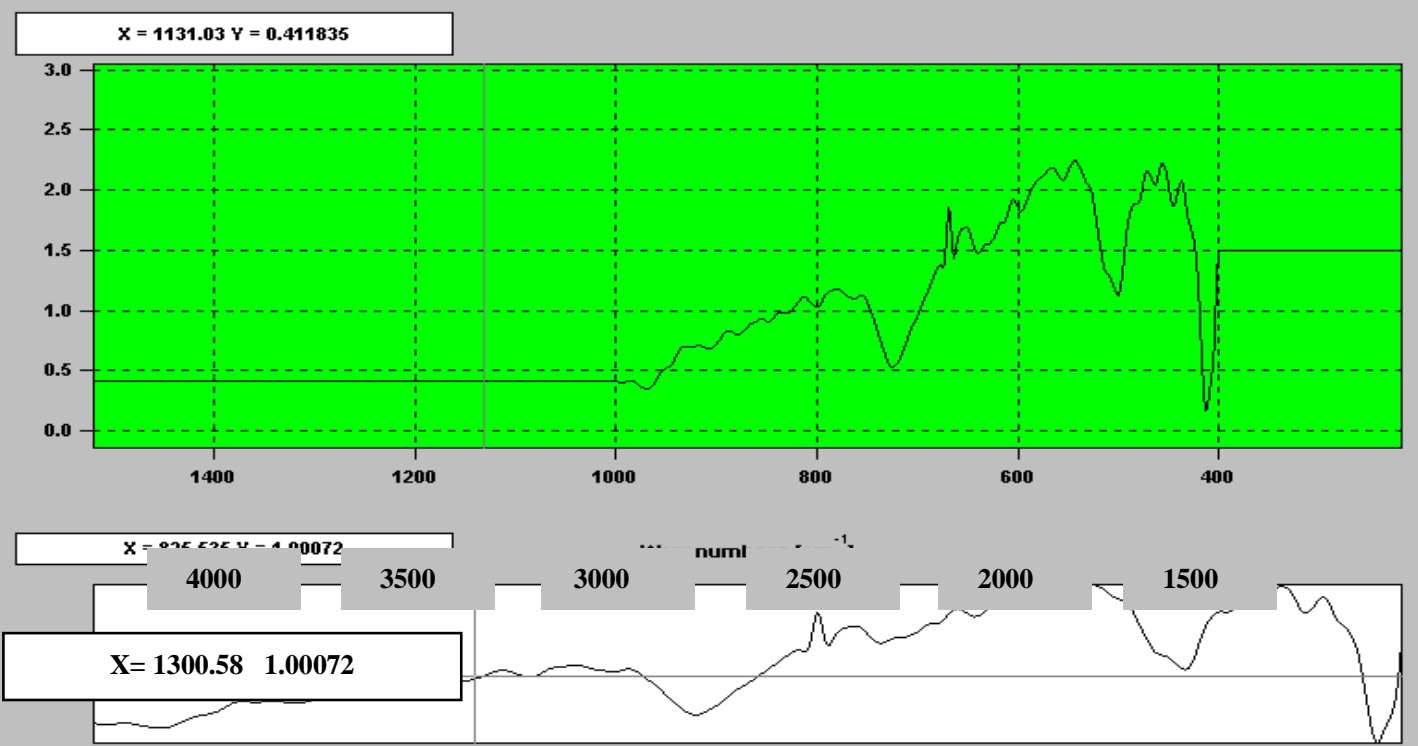

Available memory: 28464

The sharpest peak of IR chromatogram for vitamin A appears at a wave number $=1720.05 \mathrm{~cm}^{-1}$

\section{View - 'NONAME}

File Édit View Process @pptions Help

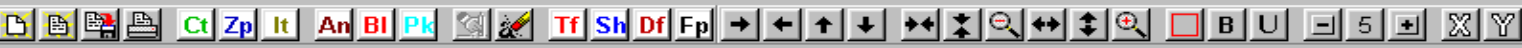

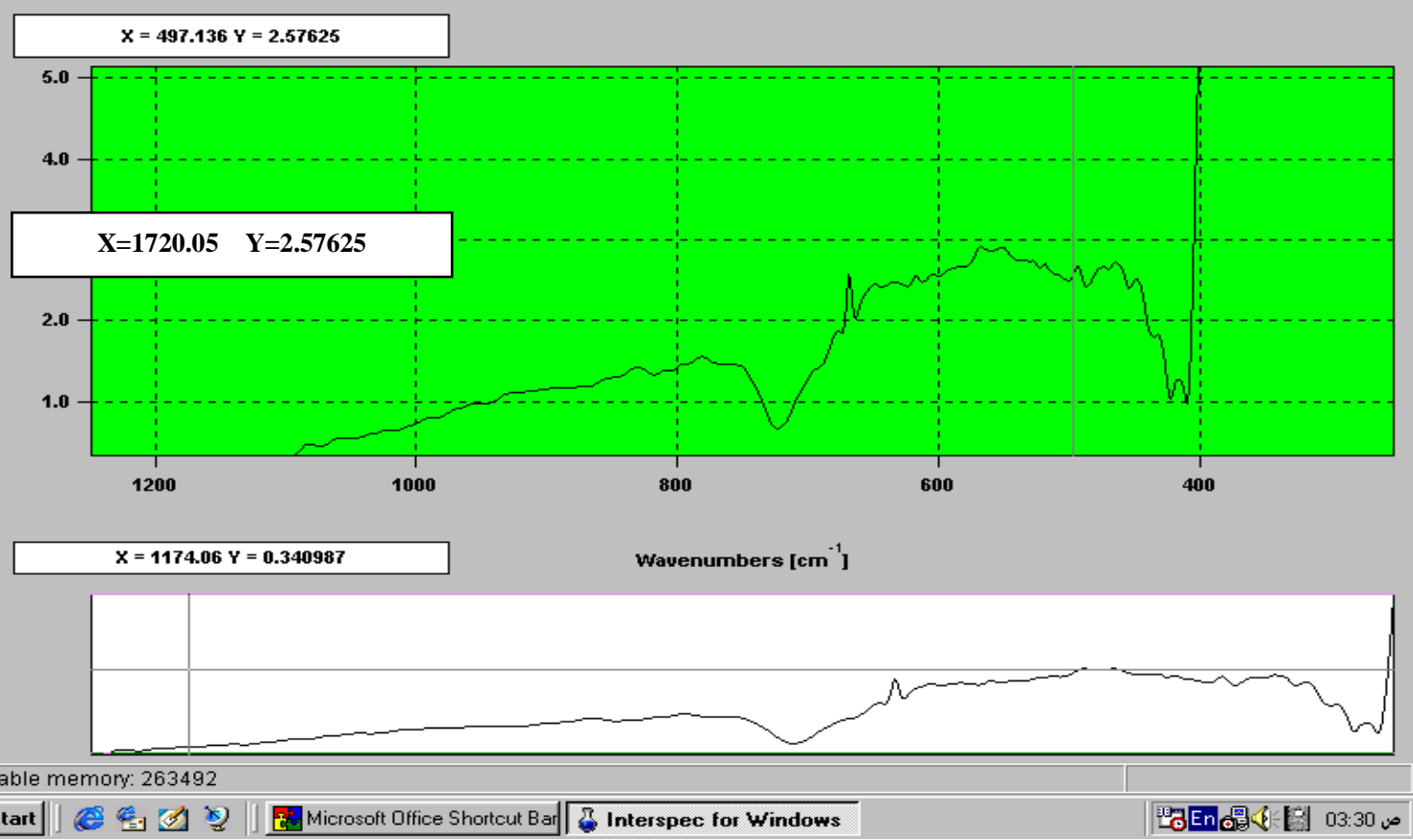


Figure (4.4.3.1) :IR chromatogram of vitamin A sample. The sharpest peak of IR chromatogram for vitamin A for the second sample appeared at a wave number $=1720.05 \mathrm{~cm}^{-1}$

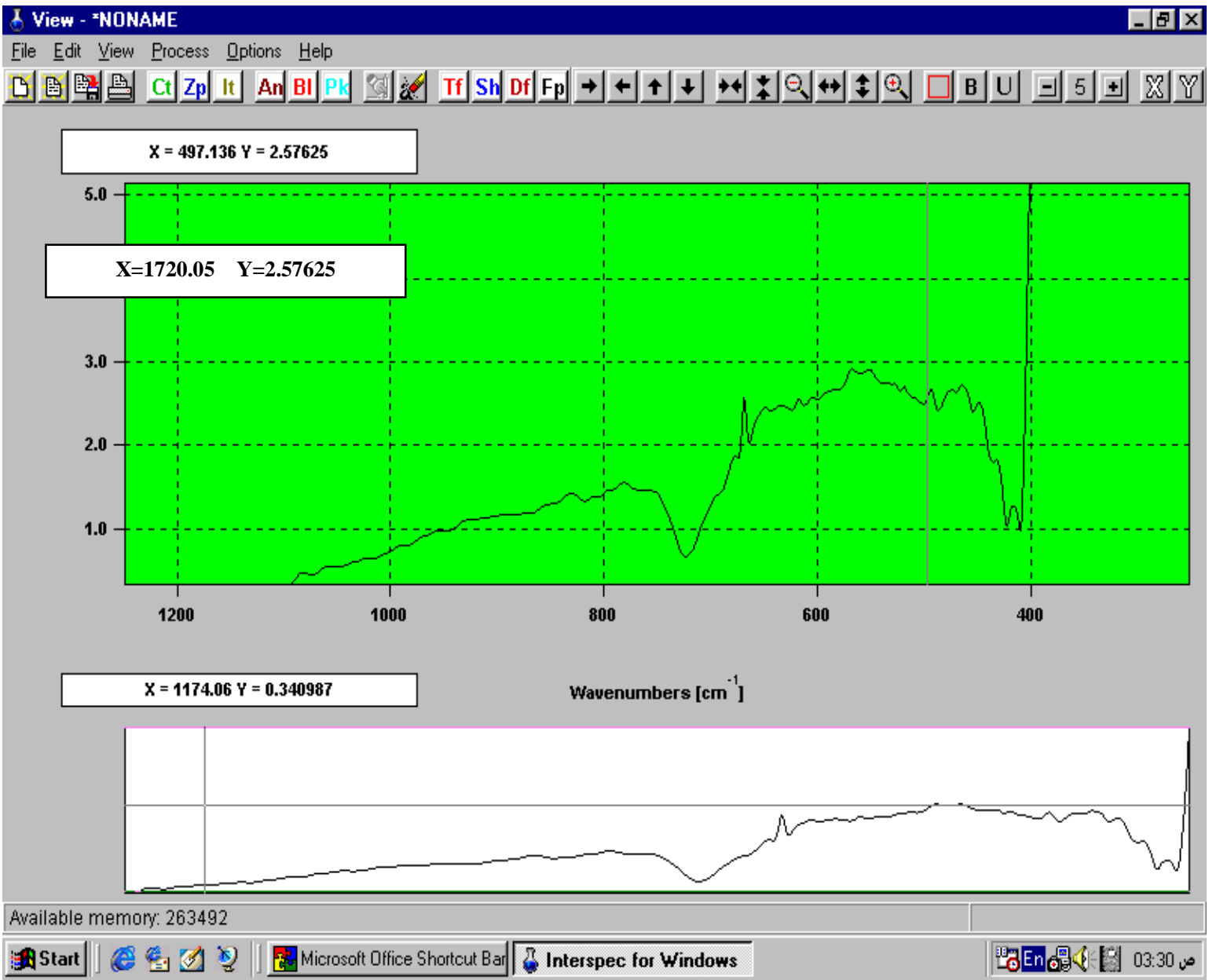

\subsection{Discussion}

The main purpose of this project was to produce a very important pigments to use it in the treatment of coeval diseases such as the cancers .

As can be seen in Figure (4.1), 90 days needed to reach the suitable cell number of 780 million cell/ $\mu$ lo be harvested using centrifuge at 4000 r.p.m.

Extraction of $\beta$-carotene from 2.885 gr precipitated cells was by the means of jojoba oil. The color of jojoba oil solvent changed from light to dark yellow which gave a good indication of $\beta$-carotene presence, as shown in Figure(4.3)

The central cleavage of one mole of $\beta$-carotene using 15,15 '- $\beta, \beta$-carotene dioxygenase enzyme produced two moles of vitamin A (tretinoin).

The product was analyzed using infrared spectrophotometer to detect the presence of $\beta$-carotene and tretinoin at a specific wave number. Many trials were performed for each $\beta$-carotene and tretinoin sample. The wave number of IR spectrometer can be identified by the sharpest peak appears at the chromatogram, the wave number affected by many variables such as concentration and, temperature.

Firstly IR analysis was performed for the sample before the oxidative reaction (extracted $\beta$-carotene). The sharpest peak appeared at $2905.5 \mathrm{~cm}^{-1}$ for the first trail , $2868.8 \mathrm{~cm}^{-1}$ for the second trial and $2902.9 \mathrm{~cm}^{-1}$ for the third one.

After the oxidation reaction carried out for one hour the product was analyzed by IR spectrophotometer and the sharpest peak appeared at wave number $=1720.05 \mathrm{~cm}^{-1}$ for the first trial and $1612.03 \mathrm{~cm}^{-1}$ for the second one. Finally IR analysis for standard vitamin A was carried out in order to have a reference wave number range ( $1512.03-2920.02) \mathrm{cm}^{-1}$.

Jojoba oil was chosen as extraction solvent due to 
Jojoba oil is used medicinally. It contains vitamins E and B complex. It also has the minerals silicon, chromium, copper and zinc. It has a very high percentage of iodine. The iodine concentration gives the Jojoba oil a great power to heal.

II Jojoba is liquid wax highly penetrating and closely resembles human serum. Anti-inflammatory, antioxidant.

II Jojoba oil is rich with vitamin $\mathrm{C}$, as well as possessing sulfur, copper, and cobalt and has traces of tin.

\subsection{Conclusions:}

1. Dunaliella has no protecting wall, centrifuge used to break down the cells and $\beta$-carotene extracted out of the cell.

2. $\beta$-carotene accumulates in Dunaliella cells when it exposed to high light source or by the limitation of nutrients .

3. Harvesting by centrifuge separate the cells from suspension.

4. $\beta$-carotene is soluble in fatty oils, so jojoba oil extracted $\beta$-carotene sufficiently .

5. $15,15^{\prime}-\beta, \beta$-carotene dioxygenase enzyme cleaves the symmetrical $\beta$-carotene molecule into two tretinoin molecules .

6. IR spectroscopy used in the qualitative analysis of the products.

7. Wave numbers for both $\beta$-carotene and tretinoin are located in wave length range of Vitamin A .

8. The economic potentiality of the produced natural $\beta$-carotene and vitamin $\mathrm{A}$ ( tretinoin) is very high since the purity was $99.63 \%$ according to the HPLC analysis.

\subsection{Recommendations}

1 - Performing the process of $\beta$-carotene and vitamin A production on pilot plant scale.

2-Verification of the produced vitamin A as far as the concentrations of heavy metal ions are concerned.

\section{ACKNOWLEDGEMENT}

This work has been carried out during the sabbatical leave granted to Dr.Sadeq Emeish from Al-Balqa' Applied University (BAU) during the academic year 2013-2013 in Mutah University.

\section{REFERENCES}

[1]. Mordhay Avron, Amin Ben-Amotz, Dunaliella Physiology, Biochemistry, And Biotechnology, Haifa, Israel / 1997.

[2]. Emeish, S., Daghistani, H., Barjakli, Y., Halophilic Algae and Bacteria of the Dead Sea as A ournal of Applied Science, 2003, Volume 5, No.2, P.15-26.

[3]. Oren, A. 1999b. The Rise and decline of a bloom of halophilic algae and Archaea in the Dead Sea: 19921995. In: Microbiology and biogeochemistry of hypersaline environments. Oren, A. (Edit). CRC Press. London. pp 129- 139.

[4]. Nader Faried J. AbuSara, a thesis under the title "Optimal Growth Conditions for the Production of $\beta$ carotene and Glycerol from a Halophilic Microalgae Dunaliella sp. Isolated from the Dead Sea" Jordan University of Science and Technology (J.U.S.T) January, 2004.

[5]. Mordhay Avron\& Ami Ben-Amotz, Morphology .In: Dunaliella physiology, Biochemistry, and Biotechnology. CRC press Boca Raton Ann Arbor London Tokyo, 1997.

[6]. Caroline Wheater, Beta-carotene: Webster's Timeline History, Icon Group International , 1946 - 2007. Richard Passwater , $\beta$-carotene and Other Carotenoids (Keats Good Health Guides), Georgiana GordonStrachan ,1988.

[8]. Leiv Haugen and Terje Bjornson, Beta Carotene: Dietary Sources, Cancer and Cognitio, Icon Group International , 1986.

[ 9]. Emeish, S., Daghistani, H., Barjakli, Y., Halophilic Algae and Bacteria of the Dead Sea as A ournal of Applied Science, 2003, Volume 5, No.2, P.15-26.

[10]. AbuSara, N., Emeish, S.,Sallal, A., The Effect Of Certain Environmental Factors on Growth and Beta Carotene Production by Dunaliella s.p. Isolated from the Dead Sea, Jordan Journal of Biological Sciences, Volume 1, Number 1, 2011, P.29-36 